\title{
Evaluation of an Anglo-Centric ELT Textbook in Bangladeshi Context: A Case Study
}

\author{
Md. Humayun Kabir*
}

\begin{abstract}
With the advancement in human civilization and human understanding we are now bold enough to ask the value of and rationale for something imposed on us by any quarter. If carefully observed, it is evident that BANA (Britain, Australia and North America) country materials have dominated the ELT (English Language Teaching) related field for quite a long time. We anxiously notice that in these materials the socio-cultural background of the vast community of ESL/EFL users (learners and teachers) is grossly ignored. Since the learner's background knowledge i.e. 'schema' is an issue of paramount importance in ELT, in this study our attempt is to assess and justify the suitability of the Anglo-centric ELT textbooks titled Foundation English Course (FEC) Book-I\&II which is designed to teach the students of REC (Remedial English Course) programme at IIUC (International Islamic University Chittagong).
\end{abstract}

Key Words: schemata, culture and context, cultural appropriateness, cultural imperialism, home culture.

\section{Introduction:}

International Islamic University Chittagong (IIUC) has made Foundation English Course (FEC) obligatory for the undergraduate students of all the departments, who fail to qualify the EPT (English Placement Test) in the very beginning of their graduate study. Around 400 to 500 students register this course in every semester, and 10 to 12 teachers are assigned to conduct these courses. It is believed that 'this FEC programme helps them (the students) pursue their degree

\footnotetext{
* Associate Professor, Dept. of English Language \& Literature, IIUC.
} 
effectively so that they can contribute significantly to their respective fields in practical life as professionals, where skills of English will give them an extra edge' (Mahmud, 2010, p.7).

Department of English Language and Literature of IIUC has published two textbooks namely FEC BOOK-I \& II for the students who have to do REC (Remedial English Course), and these two textbooks are mandatory for all students. In the Preface of Book-I it is stated: 'the exercises are directed towards any of the four major skills. They reflect realistic, typical language use and are relevant to the students' concerns, daily lives and life experiences. It only covers the basic areas of four major skills to help the students become confident, comfortable and independent in English'. Being one of the long time practising teachers of this REC programme, I have observed that the majority of the text and tasks are culturally unfamiliar and irrelevant to our students and teachers. By and large, it seems to us that it is an Anglocentric textbook. The teachers and students alike often complain that REC programme is unable to achieve the desired objectives. The students have serious problems with these textbooks. As a regular user of these books we have to explore whether these books are supportive enough to achieve the desired objects.

We know acculturation of English as a Second/ Foreign Language (ESL/EFL) materials according to the learners' local context is one of the much talked about issues of the day in an ELT textbook design; for example, Bamon (2004) claims that greater emphasis ought to be laid upon the publication of 'local teaching materials'. We also have to acknowledge the importance of background knowledge of learners for the sake of the better understanding of the provided materials, or else it will not achieve the target of language teaching. This is the reason why the schema (the learner's background knowledge) theory has been developed (see 2.2).

Here, in this study, we attempt to examine the materials (FEC textbooks) used for the REC programme in order to ascertain to what extent they are suitable in the context of Bangladesh in general and in the context of IIUC in particular.

We expect this study will expose the problems (if exist) with this text and tasks, and make the authority concerned aware of the problems and disadvantages of using these materials for the REC programme. 


\subsection{The structure and contents of FEC BOOK-I \&II:}

The FEC books are designed to teach the $1^{\text {st }}$ and $2^{\text {nd }}$ semester students of the undergraduate programme at IIUC, who fail to qualify themselves in a placement test. It is a mandatory course for them, and these FEC BOOK-I \&II are taught in the class. FEC Book-I contains English Morphology and Syntax \& Reading skill. And FEC Book-II includes Writing skill \& Listening and Speaking skill. The students have to spend at least 1year to complete this course. If any student fails to obtain pass marks in any of the skills stated above, she/he must resit and achieve pass marks before the completion of graduation.

\subsection{Who publish the FEC books? :}

Four teachers of the department of English Language and Literature of IIUC have worked together to edit the book. They have taken different lessons from different sources and compiled them together. IIUC has provided the fund and the department of English Language and Literature of IIUC has published it. By this time (2011) these books have been reprinted four times.

\subsection{The objective of FEC programme:}

The objectives of this course are not clearly mentioned anywhere. However, in the preface of the book, it is categorically stated that " we strongly believe and hope that the materials supplied in Foundation English Course will prove effective in carrying a student from the beginning stages of learning to use English to full competence in fulfilling the requirements both in university and in professional life'. Here, we can have an idea about the objectives of this course. We presume this course and the textbooks will enhance students' communicative and linguistics competence.

Now we will have a literature review in the following discussion with a view to exploring the idea of appropriate materials for the learners to ensure effective learning and teaching.

\section{Literature Review:}

\subsection{Context in Language Teaching:}

In language teaching, the need for considering the context is becoming increasingly noticeable. Hymes (1972, p. xix) for example remarks, 'the key to understanding language is to start not with language, but with context'. 
EFL 'pedagogy' is experiencing a growing awareness of the importance to instruct a foreign language by adapting it through locally appropriate 'context' (Kramsch, 1993). The necessity of the local context is due to the fact that to explain linguistic input of the target language, learners cannot 'completely separate' themselves from their local context; rather they draw upon the background knowledge they have acquired from their home culture.

We can develop communication activities which place importance to social as well as functional features of communication. 'Learners must still aim to convey meanings effectively, and must also pay greater attention to the social context in which the interaction takes place' Littlewood (1981, p.20).

As in teaching a foreign language cultural appropriateness is a fundamental factor, it is important to understand what it means by the term 'cultural appropriateness'. According to McGrath (2002), cultural appropriateness is 'the absence of any features (illustrations or verbal references) that offend against the religious, social, political mores of that culture; more broadly, it might be seen as the framework within which the materials are set, and the extent to which settings, interactions and characters are familiar' (p. 106).

Successful language learning demands language users to know the culture that underlies a language. It is a fact that learners' cultural background impacts their ability to understand the text. Understanding the culture of the text is a prerequisite for successful language learning. It is true that without the appropriate cultural schema to aid understanding, what is learnt must necessarily be partial. Between language and culture there exists a very deep and close binding. They are so closely interwoven that one cannot be isolated from the other. A language is a part of a culture and a culture is a part of a language; these two are firmly interwoven.

\subsection{Learners' schemata: local context in ESL/EFL materials}

We know a schema is a mental framework based on past experience developed as a means of accommodating new facts, and hence making sense of them. We assume schemata can play a vital role in understanding, and it is background knowledge on which the interpretation of a text depends. When different kinds of pollution in Bangladesh are mentioned in a reading text, for example, the reader's mental scripts about different types of pollution will be activated in 
memory as a natural part of the comprehension process. 'Learners of a second language need practice in activating schemata in comprehension, otherwise they are likely to engage in BOTTOM-UP PROCESSING only, which will mar their ability to comprehend speedily and naturally' (Johson \& Johson, 1998, p.283).

In ESL/EFL materials, 'cultural appropriateness' is crucial because foreign language learners combine their background knowledge with the information in the text (Widdowson in Grabe, 1988). In this way, learners interpret new things depending on their schematic knowledge. However, 'schemata vary according to cultural norms and individual experiences' (Cook, 1997, P. 86), which further emphasises that materials need to be designed based on the local context and culture of ESL/EFL learners. So, before introducing the idea of a pub or Para suit jumping, materials designers need to think as to whether the intended learners have ever experienced those things in their home culture.

\subsection{Need for Local Identity via Local materials:}

EFL learners should have 'local identity' (Bamon, 2004) because L2 acquisition and use are really associated with the 'issue of identity' (Chao, Nagano, Luna \& Geist, 2000 in Lin, 2009). Indeed, learners' 'self-identity', stemming from 'home culture' makes learners more confident in communication through the target language.

It is presumed that cultural appropriateness is one of the preconditions that makes learning easier and more effective. It is also found that people with same cultural background (of a country or region) have an identical language learning inclination. In the field of language teaching, it is also known as 'cultural profiling'. Koranic attitudes to thought and language is noticed in the studies of Dudley-Evans \& Swales (1980), Osterloh (1986) and Parker et al. (1986) among the students from the Middle East. Similarly, Bowers (1980a) speaks of the influences of Buddhism in India on the study modes of students discussed in Chapter-4 (in Holliday, 1994).

In an ESL/EFL teaching context, establishing social identity is important because the classroom cannot be isolated from the society, rather it is a part of the society. Pennycook (2000) claims that learners do not leave their 'social relations', their 'rituals upbringings' at the classroom entrance; rather, they take them in with them. From that perspective, the classroom works as a 'microcosm' of the whole society which the EFL/ESL learners belong to (Aucrbach, 1995, in Pennycook, 2000). 
As the ESL/EFL classroom is a part of a particular society, materials and activities for the class ought to be designed according to the social realities of that particular locality so that those materials and activities 'link explicitly to what the learners already know...'(Haward \& Major, Not Dated; p.104). Bell and Gower (1998) posit that locally produced course books, 'if well produced' have a greater 'chance of success' because the local material writers are well aware of the needs and background of the learners in that particular region.

The study will now explore how different views on literacy anticipate the need for culturally specific materials.

\section{Research Methodology:}

As mentioned in the introduction, this paper will now investigate how far an Anglo-Centric ELT Textbook reflects ESL/EFL learners' own cultural and contextual issues. In doing so, it will precisely focus on: Reading skill, Writing skill and Speaking and Listening skill parts of FEC Book-I \& II. In this case, the study will be limited to the needs of the Foundation English Course (FEC) students at International Islamic University Chittagong (IIUC), Bangladesh.

An ELT research can be carried out following either a survey strategy or non-survey strategy (see, Brown, 2001). A survey research is carried out through questionnaire and interview instruments while a non-survey research can be carried out based on an existing theory or based on the review of existing literature. As in this study our aim is to evaluate an ELT material (FEC Book-I\&II), a non-survey strategy is more appropriate than a survey strategy.

In this research, an evaluation approach is used drawing on the literature review and the materials evaluation models suggested by Cunningsworth (1995), Johnson \& Johnson (1998) and McDonough \& Shaw (2003).

However, we will pay special attention to the model of Johnson \& Johnson (1998). Here we feel that we should briefly discuss the approaches to materials evaluation in the subsequent discussion.

Materials evaluation includes both the 'macro' and the 'micro' level evaluation (McGrath, 2002, p.14). 'Macro' level evaluation is also known as, 'impressionistic overview' (Cunningsworth, 1995, p.1), 'external evaluation' (McDonough \& Shaw, 2003, p.61), can be used 
to quickly examine the information given on the 'blurb', 'introduction', or 'table of contents' (McDonough \& Shaw, 2003).

Evaluation at this state is often superficial. Once a 'macro' evaluation is done, the textbooks or materials need to be evaluated at a 'micro' level, also termed as 'internal evaluation' or, 'in-depth evaluation' (McDonough \& Shaw, 2003). Evaluation at this stage goes beyond what the materials writer and the publishers 'claim' about the materials (McGrath, 2002, p.27).

In the 'internal evaluation' stage, the validity of the 'claims' by the materials writers and publishers made on the 'blurb', 'introduction', or 'table of contents' etc. are closely examined and tested as to whether the 'factors in the external evaluation stage match up with the internal consistency and organization of materials as stated by the author or publishers' McDonough \& Shaw (2003, pp.66-67).

For an overview of the ELT materials evaluation checklist, Johnson \& Johnson (1998) model is given below.

\subsection{An Ideal Model for Materials Evaluation:}

The model in Figure-I addresses most directly the situation in which institutions or teachers depend mainly or exclusively on commercially produced materials, typically in the form of 'the textbook for the course':

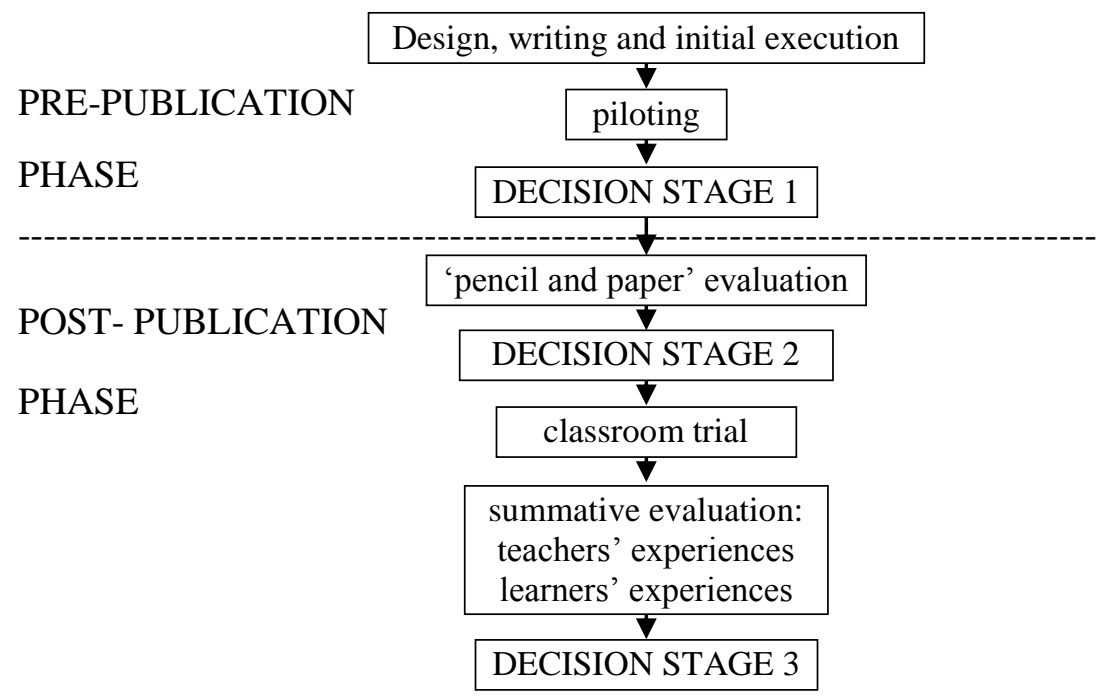

Figure 1 The schema proposed as an 'ideal' model for the materials evaluation process. 
In the model, it is assumed that preliminary decisions made by materials designers to compile them, by commissioning bodies to order them or by publishers to issue contracts, come at the stage of design, writing and initial execution. It is also assumed that the beginnings of the evaluative process, though perhaps not formally conducted, will be implicit in the acceptance or refusal of a proposal or a manuscript by publishers, and with the designer's reflection upon whether correct options are being pursued at each point in the design. When ready in a draft form, the materials are piloted on a sample of the target population, and the results of the pilot lead to DECISION STAGE 1, at which the materials are declared acceptable or in need of modification or are rejected. The materials then pass into the public domain and are subjected first to a 'paper and pencil' evaluation that is, evaluators assess them by inspecting them, but without trying them out on the sub-population, or a sample of it, with which they are directly concerned-the learners in their own school, for instance. At DECISION STAGE 2 the evaluators decide which materials to select for further consideration and which to reject on the basis of the evidence. The classroom trial of the materials passing the 'paper and pencil' evaluation leads into the summative evaluation, in which all the information gathered, including the reactions of teachers and learners to the materials, is assembled. At DECISION STAGE 3, certain materials are adopted and others declared unsuitable.

We understand that not all materials are piloted before release, classroom trials are rarely feasible and not all teaching authorities consult learners, or even teachers, on their opinions of materials. A particular problem with classroom trials is the expense involved in purchasing sufficient sets of materials to test on an adequate sample without any commitment to using them beyond the duration of the trials. For this reason and others, the checklist is accorded importance, since it is precisely a recipe for the 'pencil and paper' evaluation.

\section{Data analysis, Findings and Discussion :}

From an 'in depth evaluation' (McDonough \& Shaw, 2003), it is noticed that the FEC BOOKS have different sections on vocabulary, reading, grammar, writing, listening and speaking; thus, it may be regarded as an integrated approach.

\subsection{Analyzing Book-I:}

This book consists of the following contests:

1. Morphology 
2. Syntax

3. Reading \&

4. Vocabulary

From our analysis, the discussion on Morphology and Syntax in BookI seems quite well. A wide area of these contents has been covered. However, from our study, it seems that the discussion is too lengthy and the exercises are excessive in terms of items. Neither the teachers can finish those in the class nor the students are able to solve them at home. As a result a sizeable area remains untouched at the end of the academic session. As a teacher, I could not finish and neither could finish my other colleagues. Moreover, I noticed that the coordinator of this REC Program cut short the syllabus; as a result, this wide discussion serves only the ornamental purpose. Another important aspect of the textbook is that different parts of language items are presented separately. It is believed that grammar should be viewed from a holistic outlook. We have to understand that we do not acquire language in additive manner. Nunan (1988, p.30) holds "evidence from second language acquisition (SLA) research suggests that learning does not occur in this simple additive fashion." So more integrated approach may be taken with a view to teaching grammar skills more effectively. Besides, the exercises at the end of each lesson are presented in a discrete manner. We presume if some comprehensive tests on grammar skills could be developed, students could have benefited much. The same observation is applied to the syntax part.

\section{Reading Skill}

Book-I contains around 30 reading comprehension tasks. Among them as many as 14 passages are chosen from our unknown contexts, our study reveals. Below we present a list of the titles of those culturally unfamiliar topics: Do You Laugh a Lot' , 'Hogmanay', 'Dream', 'Plastic Surgery', 'Equal Pay' 'Calendars', 'Ten Years Without Books', 'The French Revolution', 'Malnutrition', 'How Do You Handle Your Stress', 'The Co-operative Movement' 'Technophobia' 'Equal Pay'. Now we shall discuss four reading passages taking as samples from Book-I below:

In the above mentioned reading passages, we find various issues and features which are totally new to our students. The passage "Hogmanay" deals with a Scot words. It is about New Year celebration in Scotland. The way it is celebrated and the functions that 
are organized are so much peculiar and absurd that let alone the students even the matured reader will be in trouble to understand it. Here is a little citation for the examination:

"...An example of a local Hogmanay custom is the fireball swinging in Stonehaven, north-east Scotland. This involves local people making up balls of chicken wire, tar, paper and other flammable material to a diameter of about a metre. Each ball has two metres of wire, chain or non-flammable rope attached. The balls are then each assigned to a swinger who swings the ball round and round their head and body by the rope while walking through the streets from the harbour to the Sheriff Court and back. At the end of the ceremony any fireballs which are still burning are cast into the harbour. ..."

"...The celebrations planned for this year include a street party with music varying from French hip hop to Jamaican reggae and ska. The evening will also have a fireworks display, organized by the man responsible for the Athens Olympic firework display. The scale of the event is reflected in the fact that people from all over the world are expected to attend. ..."

"Dream" is a reading passage where the readers encounter lots of new terms, phrases and ideas. Sometimes it appears that this passage is meant for doctors or neuro-medicine specialists. Let us observe the following quotations from the passage:

"...The electrical activity of the brain is similarly quiet; for most of this period only theta and delta waves, 4-7 hertz (cycles per second) and 1-2 hertz respectively, occur. The eyes do not move, and there is a slight muscular tension, especially in the region of the throat. When sleepers are awakened from this form of sleep, which is known as orthodox, or NREM sleep, it is unusual for them to report that they have been dreaming...",

" "... The EEG waves of the brain speed up to the alpha (8-12 hertz), and beta (13-22 hertz) levels. This is 
REM, or rapid eye movement sleep, so called because during it the eyes move rapidly, upwards and downwards, and from side to side. There is also a relaxation of muscular tension. ..."

The passage "How Do You Handle Your Stress" contains irrelevant ideas to our context. The thought is not at all familiar to our students. This sort of experience is entirely new and unusual here. Now we will study some extracts of the passage to examine its contextual appropriateness:

"...The researchers discovered in their tests that the system of cell reproduction and replacement, which of course keeps us going, becomes faster under duress. Each time a cell in our body is replaced, part of our DNA, called telomeres, shorten. When these telomores become too short, cells cease reproducing and our bodies continue the aging process. This means longer telomeres lengthen our lives. Stress makes them shorter, and so we die prematurely. The simple message, therefore, is to take life easy. Research leader, Dr. Elissa Epel, compared 39 women who looked after children with chronic illnesses with a 'control' group of 19 mothers of healthy children. The length of the life-giving telomeres was then measured in their blood. The women who had the more stressful task of caring for chronically ill children aged the equivalent of ten years compared with the other women. ..."

The reading passage "Do You Laugh a Lot" contains an idea which is silly and atypical in our society. It is a European or $1^{\text {st }}$ world's issue. In our day to day life, we never imagine such a situation. The idea which we never experience, the occurrence that never happens in our day to day life, the instance that is hardly found, how can we select it for language teaching? Here are some extracts below:

"...When you are down on your luck, it may be the last thing on your mind. But in Austria doctors know the health value of a good chortle, and are offering homeless people lectures on how to laugh. The project began in the southern city of Graz in October 2004. It has been such a success that other disadvantaged 
groups, including asylum seekers, are about to be taken on as students...'

"...The courses are conducted by professors such as Leopold Neohold from the Karl Franzens University in Graz, who have been to four local hostels to deliver a lecture called 'Laughter is the best medicine'. 'This is a fantastic project' he said, 'One of the main problems for the homeless is getting a foot back in the door of society ... we hope this programme will be the first step towards achieving that goal'. The project is sponsored by a magazine called Megaphon, which supports homeless people. Dr Neohold said his first 30 homeless students had learned the importance of humour in the face of adversity, and added, 'It demonstrates that education should be open to everyone, including the homeless'. 'Anyone who completes a course will be given a certificate, and I'm sure it will give them back a degree of respect'...'

Because of some practical considerations and space constraints, we cannot analyze anymore passages here, but we present some of them in the form of appendix for the reader's convenience.

However, we presume if some of the passages were adapted considering our contextual background, they would have been more effective and suitable for teaching and learning. Stern (1983, p. 283) maintains "for language teaching, it is important to relate language and society, because language are taught and learnt to establish contact and communication across language boundaries'. The importance of the consideration of social context is always viewed as a matter great importance indeed.

For example, the passage titled-"Malnutrition", "Pollution", "Changes in the Village" "Co-operative Movement" "Equal pay", etc. might have been adapted by applying following techniques like localizing, personalizing, individualizing, adding, and modifying. We may apply these techniques 'to maximize the appropriateness of teaching materials in context, by changing some of the internal characteristics of a course book to suit our particular circumstances better' (McDonough \& Shaw 2003, p.76) . 
We presume, in that case these passages could have attracted both teachers and students.

\subsection{Analysing Book-II}

This book contains the following contents:

1. Writing and

2. Speaking.

From our study, it is exposed that majority of the writing tasks are contextually irrelevant, and some tasks are even shocking to the users of this book. Almost every task is Anglo centric. Our learners scarcely experience this sort of things. In Bangladesh perspectives, the writing skill is one of the most required skills. In different offices, it gets the top most priority. Our writing activities must be contextually fit and effective.

In this writing section, we hardly notice the reflection of this truth. We present some examples below:

1. Writing about Directions,

2. Writing about weather,

3. Writing a newspapers report,

4. Writing a biography,

5. Describing festivals and ceremonies,

6. Describing a book, play or film,

7. Writing about past events,

8. Describing a place, and

9. Writing notes, messages, notices and advertisements.

In these above tasks, the very names of the people are foreigners, the places mentioned here are European, and the incidents are not contextually familiar. The interactional activities are peculiar and absurd as we do not experience such kinds of matters. The language functions and the notions that we find here are quite unnatural to our students. Even the weather patterns, festivals (Nottingham Hill Carnivals) places, social activities (going to disco), events which are mentioned / discussed/ described are strange and unbecoming to our students.

Almost the same sort of Eurocentric ideas / issues / facts / incidents / events / interactions /communications, etc. dominate the listening part. We presume these activities/ tasks cannot contribute to learning effectively. It would have been better if those tasks / texts were contextually and culturally familiar to the learners .It is widely recommended that materials should aim to be in some sense "communicative", and "authentic", We should keep in mind: 
'language is for forming relationships with people and for interrelating with them. Using language means meeting people and talking to them. The aim is to give the students the ability to engage in conversations with people' (Cook, 2008, p.252).

\subsection{Findings:}

From an overall evaluation, it may be suggested that most of the lessons of FEC books are not appropriate ELT materials for the REC students at IIUC.

However, the author thinks that some of the features of the unit integrative approach, stimulating classroom interactions and cognitive skills may be very useful for the FEC students if the contents in the unit are changed according to the socio-cultural background of Bangladesh. Some of the activities may be really rewarding for the REC students at IIUC if the context and the title are changed to match them both with the background knowledge of the learners and with the socio-cultural and socio-economic aspects of Bangladesh.

Our study further reveals that there were no systematic material development and evaluation (pre/post publication) of these FEC textbooks. As a result, nobody knows whether these books are achieving the desired and stated objectives. More importantly, the IIUC authority has never ever taken any initiative to evaluate it with a view to finding its suitability. All of us are well aware that these materials are published by the Department of English Language and Literature of IIUC.IIUC cannot deny its ownership and the criticism it incurs.

After all, it is a matter of the image of a university. It is a fact that students pay separately both for the materials and the courses (FEC).They can rationally expect an effective language programme and quality materials from IIUC for which they are paying. It will be considered an injustice as well as an unmerited move if the problems are not addressed quickly. It is high time the competent authority took the necessary steps to make the materials of desired standard with the help of the experts in this area.

\section{Pedagogical Implications:}

From the findings of the research, it may be suggested that in adapting or adopting ELT materials for a group of learners, ELT practitioners need to evaluate the materials as to whether they are socio-culturally and cognitively responsive to those learners. However, it is also equally important to suggest that ELT teachers need to be trained in 
the appropriate skills so that they can evaluate when adapting or adopting an ELT material. Doganchy-Aktuna (2005) claims that to make the teachers more aware of socially appropriate 'pedagogy', social awareness raising activities need to be introduced in ELT teacher training. Freeman \& Johnson (1998) claim that teacher education should be re-conceptualized so that it 'responds to the basic sociocultural process of learning and to teach' (p.397).

We believe the study will surely help the language teachers and materials publishers to understand the value of schema to make language teaching effective. Besides, the authority of IIUC will also realize that the existing REC Books are not as effective as they were assumed to be and the authority concerned will take pragmatic steps by engaging proficient materials developers with a view to publishing more useful teaching materials without making any delay.

\section{Conclusion:}

This paper has made an attempt to explore the need for considering learners' own socio-cultural context in adapting or designing ELT materials and classroom activities. It has been observed from the literature review that 'globally' designed materials may not always meet learners' social or linguistic needs.

In addition, the paper has examined the FEC books as to whether they can be used as a material in the context of Bangladesh. Here it has been suggested that if some of the present contexts and contents of the FEC books are acculturated according to the social context of Bangladesh, the activities in the material can be very useful for the FEC students at IIUC in Bangladesh.

Finally, the whole study is an effort to demonstrate that materials and methods that can be appropriate for one group of learners in a particular society may not be so in case of other group of learners in another country or society. Hence, based on the findings of the research, we can conclude with what McDonough \& Shaw (2003) suggest : 'what may work well in Mexico city may not do so in Edinburgh or in Kuala Lumpur' (p. 87).

\section{References:}

Bamon, T. K. (2004). The English text: Establishing identity. IATEFL Newsletter. Retrieved from http://ttedsig.iatefl.org/resources/e-newsletter/TheEnglishText.pdf

Brown, J. D. (2001). Using survey in language programs. Cambridge, Cambridge University Press. 
Bell, J. \& Gower. (1998). Writing course materials for the world: A great compromise. In Tomlinson, B. (Eds.), Material development in language teaching. Cambridge Language Teaching Library.

Cook, G. (1997). Key concept in ELT: Schemas. ELT Journal 51(1),86.

Cook, V. (2008). Second language learning and language teaching. Great Britain: Hodder and Stoughton Limited.

Cunningsworth, A. (1995). Choosing your course book. Oxford: Heinemann.

Doganchy-Aktuna, S . (2005). Intercultural communication in English language teacher education. ELT Journal 59 (2), 99-107.

Freeman, D. \& Johnson, K. E. (1998). Reconceptualizing the knowledge-base of language teacher education. TESOL Quarterly 32 (3), 397-417.

Grabe, W. (1988). Reassessing the term 'Interactive' in Carrell, p. L., Devine, J., \& ESkey, D. E. (Eds.), Interactive approaches to second language reading. Cambridge University Press, UK.

Holliday, A. (1994). Appropriate methodology and social context. Cambridge University Press, UK.

Hymes, D. (1972). Introduction in Cazden, C. B., John, V. P., \& Hymes, D. (Eds.), Functions of language in the classroom. Teachers' College Press, New York.

Howard, J. \& Major, J. (Not Dated). Guidelines for designing effective English language teaching materials. Retrieved from

http://www.paaljapan.org/resources/proceedings/PAAL9/pdf/Howard.pdf

Johnson, K. \& Johnson, H. (1998). Encyclopaedic dictionary of applied linguistics. Blackwell Publishers Ltd, USA.

Kramsch, C. (1993). Context and culture in language teaching. Oxford University Press, UK.

Lin, L. (2009). Second language learners' identity toward their home culture: Adding pragmatic knowledge to language learning curriculum. Asian Social Science, 5 (8), 43-51

Littlewood, W. (1981). Communicative language teaching. Cambridge University Press, UK.

Mahmud, M.R. (2010). Classroom situation in reading classes of the foundation English course (FEC) at IIUC: An empirical study. IIUC Studies, 6, 7-34.

McGrath, I. (2002). Materials evaluation and design for language teaching. Edinburgh University Press, UK.

McDonough, J \& Shaw, C. (2003). Materials and methods in ELT: a teacher's guide. Blackwell, USA.

Nunan, D. (1988). Syllabus design. Oxford University Press, UK.

Pennycook, A. (2000). The social politics and the cultural politics of language classrooms. In Hall, J. K. \& Eggington, W. G. (Eds.), The sociopolitics of English language teaching. Multilingual Matters LTD. Cleve don. Buffalo. Toronto, Sydney.

Stern, H.H. (2008). Fundamental concepts of language teaching. Oxford University Press, UK.

Document: Foundation English Course (FEC) Textbook-I \& II. Published by the Department of English Language and Literature, International Islamic University Chittagong. Bangladesh. 